\title{
Empowerment of Farmers toward Corporate Implementation
}

\author{
Siti Sehat $\operatorname{Tan}^{1, *}$ and Lira Mailena ${ }^{1}$ \\ ${ }^{1}$ Center for Agricultural Technology Research and Development (ICATAD), Tentara Pelajar Street, \\ No. 10 Cimanggu Bogor 16114 Indonesia
}

\begin{abstract}
During the last few years, farmer empowerment has been the main agenda of government programs to achieve the agricultural sector revitalization, which focuses more on human resources and farmer institutional development. Further, through the Minister of Agriculture, the government program with a target of establishing 350 farmer corporations by 2024 is a necessity if farmer groups are built with the support of the skilled and market-oriented. The assessment used a qualitative approach that focuses on data related to the assessment problem. Secondary data were obtained from various relevant literature to explore the correlation between empirical facts and government programs and regulations. The case study was conducted in October 2019 at Gapoktan Sidomulyo in Godean District, Yogyakarta Province. The results of the study showed that empirically, Gapoktan Sidomulyo is the advanced Farmer Group Association that successfully managed the farmer institution since it was supported by its history of formation and skilled human resources who were always market-oriented. On the other hand, the management of Gapoktan Sidomulyo still did not want to transform the Gapoktan into a legal business entity because it was considered more complicated and did not provide benefits.
\end{abstract}

\section{Introduction}

Agricultural development in Indonesia continues to focus on farmers' welfare as the largest part of the community involved in development but still classified as a poor community. The current government program aimed at improving the farmer's welfare is the formation of 350 farmer corporations by 2024. Farmer corporations are aimed at increasing the scale of agricultural businesses, which in turn increase farmers' bargaining position, provide farmers with better income, and ultimately have an impact on increasing the welfare of farmers.

Agricultural Minister Decree No. 18 / PERMENTAN / RC.040 / 4/2018, Chapter I Article 1, states clearly that; 1) Farmer Corporation is a Farmer Economic Institution with a legal entity in the form of a cooperative or other legal entity which most of the capital ownership owned by farmers, 2) Farmer Group Association is a group of several Farmer Groups that join and cooperate to increase economies of scale and business efficiency, and

\footnotetext{
* Corresponding Author: sititan2010@gmail.com
} 
3) Farmers' Economic Institutions are institutions that carry out farming activities established by, from, and for farmers, in order to increase the productivity and efficiency of farming, both those with legal status and those not yet incorporated. Furthermore, Article 23 states that the Farmer Corporation Institution can receive facilitation for capital assistance, infrastructure, and production facilities as well as technical and managerial assistance from the government, private sector, or non-governmental organizations.

Moreover, according to the President of Republic Indonesia, Farmer Corporation is a large group of farmers that encourage farmers to think with modern management, modern applications, in modern industrial processing methods, and at the same time market to the retail industry through online stores with professional management. Farmer corporations must be implemented so that the management of agricultural activities is transformed into a business ecosystem.

That previous description indicates that the implementation of farmer corporations is realized through the effort to empower farmers. Empowered farmers are farmers who have the strength and ability to 1) full fill their basic needs so that they have freedom, meaning free to express their opinions, free from hunger, ignorance, and freedom from pain, 2) reach productive resources that enable them to increase their income and obtain the necessary goods and services and 3) participate in the development process and decisions that affect them [1].

Empowerment is a process that includes a series of activities to strengthen the power group or empowerment of the vulnerable groups in society, including individuals facing poverty. As a goal, empowerment leads to a state or outcome to be achieved with social change, namely empowerment, power or knowledge, and the ability to meet their daily needs. In other words, empowerment is an activity or method to make the community more empowered or able to overcome problems in themselves and their environment to become independent, make choices, and solve problems [2].

Moreover, [2] describes three dimensions of empowerment, namely; 1) a development process that begins with individual growth and then develops into an enormous social change, 2) a psychological state characterized by self-confidence, usefulness and ability to control oneself and others, and 3) liberation generated by the movement social, which starts with education and politicization of the weak and then involves the collective efforts of these weak people to gain power and change the structures that are still oppressive.

Meanwhile, according to [3], farmer empowerment is an activity that involves empowered participation and leadership. Community empowerment is an effort to make human beings who are just and civilized, become more structurally useful in the life of the family, society, the state, as well as in the political and economic fields. The government's participation to achieve welfare and community independence is needed in every activity of empowerment.

Regarding farmer empowerment in rural areas, the government program often uses a group approach, such as a farmer group (Poktan) or a larger group, namely a combination of farmer groups (Gapoktan). Gapoktan is an institution that connects farmers in one village with other institutions outside the village. Gapoktan can also play the role of fulfilling agricultural capital, production facilities, marketing agricultural products, and various information needed by farmers. Government programs related to the revitalization of farmer institutions are also aimed at Gapoktan to overcome agriculture problems as outlined in the Regulation of the Minister of Agriculture No.237 the year 2007 about farmer institutional development guidelines.

During the last few years, farmer empowerment has been put on government programs to achieve agricultural sector revitalization, which is more focused on human resources development. However, there are many problems in farmer empowerment that require solutions through an empirical approach that takes into account factors that influence 
indicators of farmer empowerment and the empowerment strategies [4, 5, 6]. Moreover, one of the failures in developing farmer groups as a forum for farmer empowerment is a development process that is not carried out through a mature social process. Therefore, it is necessary to empower the farmers through the learning process of human resources and innovating farmer groups as agents of change in agricultural practices [7].

Based on those descriptions, this paper discusses the pattern of farmer empowerment as the initial capital for strengthening the farmer economic institutions and farmer corporations to transform agriculture into a business ecosystem towards prosperous farmers. The pattern of farmer empowerment cannot be separated from the forming process of farmer groups and human resources as the farmer groups' executors.

\section{Research Method}

The assessment used a qualitative approach that focused on the actual problem, whereas the preliminary assessment was carried out by looking for data on successful Farmers Association from other studies. Based on these results, Gapoktan Sidomulyo was chosen for analysis with 20 respondents, consisting of farmer group and farmer group administrators. Data collection was executed in October 2019.

This study was designed by combining literature review and descriptive research. Descriptive research is intended to describe existing phenomena, which occur at present or in the past, by examining regularly, prioritizing objectivity, and being carried out carefully. There was no treatment given or controlled, and no $\mathrm{H}$ test as well [8].

The data were collected through observation and depth interviews with the respondent. Data and information were described and interpreted according to a logical flow through the application of inductive and descriptive statistics [9]. Furthermore, the qualitative analysis was carried out based on the data taken, including (1) the initial process of forming a farmer group, (2) the number of members involved in it, (3) the initial purpose of forming the farmer group, (4) the objectives of the members involved as holders of assets/ farming capital, (5) business networks that have been carried out, (6) the number of initial and existing assets, (7) Partnerships that have been established, (8) response of farmers who have been members, and (9) response of the farmer group management to the government programs to form a legal entity group business, namely a farmer corporation.

This study's data analysis technique refers to [10], which was focused on the assessment problem. Previously, the data went through the selection stage, namely, (1) data reduction as a sorting process, focusing on simplification, and transforming raw data from interviews in the field into sorted and coded and adjusted to the focus of the study. (2) data presentation in the form of a narrative or description, which was easier to understand and more communicative.

The next stage was a secondary data study of various articles related to the writing purpose to see whether there is a correlation between empirical facts and government programs and regulations. This stage is also known as desk/library research with several data sources, including literary literature, scientific publications, and browsing from the internet.

\section{Results and Discussion}

\subsection{Determinants of Farmer Empowerment toward Implementation of Farmer Corporation}




\subsubsection{Farmer Group Formation Process}

Farmer group (Poktan) is defined as a group of farmers consisting of adult, female, male, old, and young farmers tied informally in a forum in one area based on harmony and mutual needs and directed by a farmer contact. [11] Poktan is also described as groups of farmers/ranchers/ planters formed by farmers based on common interests, equality of social, economic, and resource conditions, equality of commodities, and familiarity to improve and develop members' businesses.

Philosophically, farmer groups are formed to solve farmers' problems that cannot be faced by individual farmers. [12] Emphasizes that the formation of farmer groups is a process of consolidating agriculture. The formation of farmer groups can grow into a farmer group association (Gapoktan) as a collection of several farmer groups that join and work together to increase scale and business efficiency. Besides Poktan and Gapoktan, there are agricultural commodity associations as well, which are described as groups of farmers and farmer groups that work on similar commodities to fight for farmers' interests.

Regulation of the Minister of Agriculture of Republic of Indonesia (Permentan) No.67/2016 defines farmer institutions as institutions that carry out farming activities and are formed by, from, and for farmers to increase productivity and farming efficiency, both legal and non-legal entities [13]. Farming in this Permentan is described as an agricultural sector activity, starting from production/cultivation, post-harvest handling, processing, production facilities, marketing of products, and supporting services. This Permentan also explains that the focus of attention on farmer institutions is the farmers (main actors) and business actors in the farmer group. The formation of groups must pay attention to the same interests, natural resources, socio-economy, intimacy, mutual trust, and the existence of harmonious relationships between members for the group's sustainability.

However, farmer groups tend to be formal organizations only, so that the purpose of forming farmer groups has shifted from social groups to task groups [12]. Furthermore, the formation of farmer groups is more directed at facilitating government duties to distribute production inputs to farmers. The formation of farmer groups was initially based on a domicile approach and then modified to follow agricultural land stretch. These two approaches in the process of forming farmer groups have both weaknesses and advantages. The overlay-based approach to forming farmer groups facilitates the distribution of input products. However, the drawback is that the effort to create dynamic farmer groups with strong ties becomes more difficult because farmers who are grouped according to land stretch do not know each other.

The process of forming farmer groups, which are ideally formed by and for farmers, has begun to shift since farmer groups were formed in response to government programs that require group farmers to facilitate the distribution of aid. An example of one of the government programs is Rural Agribusiness Development (PUAP). According to [11], farmers' institutional performance in Indonesia was still not in line with expectations because farmer groups were generally formed based on technical and the concept of a uniform blueprint to facilitate coordination of government activities. They did not guarantee group independence and group sustainability.

Farmer groups formed because of a strong desire to manage the farm will develop and continue. Such farmer groups were found especially in Kabupaten Lima Puluh Kota District, Province of West Sumatra. The farmer groups that were formed and facilitated by extension agents start with community groups (recitation), farming cooperation, ethnic groups, savings, and loan groups. Generally, group members had a relationship with each other by blood (kinship, clan/ethnic group) and unrelated relationship (friendship), which was strengthened by binding elements such as a tendency to exchange goodness, mutual trust, religious/social norms, values and proactive actions from the leadership [12]. The bond as social capital then has a strong relationship with farmer participation in the group. 
It is in line with the findings of $[14,15,16]$ that the high level of participation is due to the high level of social capital in the form of beliefs, norms, cultural similarities, fate, religion, and culture. In fact, social capital as a bond between farmers and regions is also associated with faster adoption of innovations [17].

\subsubsection{Human Resources}

The success of farmers empowering in farmer groups is determined not only by the process and the initial goal of forming a farmer group but also by human resources. In fact, human resources are often referred to as determinants of the sustainability of farmer group development. The role of human resources in managing groups must be built from the beginning of group formation to running a business and developing the group

The study by [18] revealed that human resources empowerment was influenced by commitment. Commitment to the organization was a relative strength, where it was characterized by three factors, namely: 1) acceptance of the values and goals of the organization, 2) readiness and willingness to strive seriously on behalf of the organization, and 3) the desire to maintain membership inside the organization. The assessment results in the Sidomulyo farmer group provide a picture that it was following the conclusions presented by Christina and Maren. Skilled human resources and a strong commitment to advancing the organization were the strengths of the farmer groups. Apart from the commitment of members in advancing the organization, another driving factor is venture capital.

Human resources in the context of a farmer group that operates in the agricultural sector, according to some of the above theories, can be defined as people involved in the group, especially administrators who have function as the driver in the group, building the relationship among group members, managing and developing the group [19]. For this reason, human resources who act as a driving force must be the qualified peoples, have skills, work abilities, and high entrepreneurial spirit to achieve the targets and goals of farmer groups. In other words, human resources are essential for the progress and sustainability of a business.

\subsection{Farmer Empowerment as the Agricultural Human Resources}

Empowerment of farmers or farming communities is an important effort to improve their abilities and carried out through the farmer groups as institutions that organize farmers who are members of the groups. Farmer empowering through farmer groups is an effective way to assist farmers in improving their quality of life as well.

[20] stated that farmer institutions are a cooperative organization that enables the community to develop a logical response and become a forum that unites farmers horizontally and vertically. Empowerment of capital assistance is one of the empowerment concepts that have been carried out so far to overcome common problems that often occur in farmer groups, in addition to aspects of farming technology, farming management, and business management that are still traditional [21].

The impact of the empowerment program could increase economic independence, especially on productivity [22]. Nevertheless, according to [23], problems that are still inherent in farmers and farmer institutions empowerment in Indonesia are (1) the lack of insight and knowledge of farmers on production management issues and marketing networks, (2) the farmers have not been fully involved in agribusiness activities since farmer's activities still merely focused on production activities (on-farm), and (3) the role and function of farmer institutions as a forum for farmer organizations has not run optimally. 
The empowerment process requires synergy from various groups, such as the Ministry of Agriculture, Non-Governmental Organizations (NGOs), universities, and village offices. Empowerment programs from the Ministry of Agriculture in terms of empowerment in the economic sector to improve farmers' economic conditions become stronger, bigger, independent, and highly competitive in the market. One of the efforts to reach that condition is grouping farmers according to expertise and ability, namely the beginner class, advanced class, and main class. The division of farmer classes is intended to assure that empowerment within the farmer groups is in accordance with the level of farmer's ability based.

\subsection{Learning the Establishment and Management of the Sidomulyo Farmer Group Association Institution}

The existence of the Association of Farmer Groups (Gapoktan), which has a dynamic tendency to move forward, cannot be separated from the history of the formation of Gapoktan. Gapoktan that are formed based on farmers' interests will grow and develop. In contrast, Gapoktan that are grown to be used as tools or containers to get assistance/subsidies related to Government programs will be static. The formation of farmer groups in principle is to run farming together to increase and develop their farming with participatory principles [23]. The lack of farmer participation in the group shows that the farmer group's function is still not functioning [24]. One reason is that the formation of groups responds to government programs that require farmers to form groups to access the program [25].

Empirically the picture of advanced Gapoktan is at Gapoktan Sidomulyo in Godean District. Gapoktan Sidomulyo was formed in 2008, is a combination of 6 Poktan; Poktan Tani Mulyo (Dukuh Pirak Mulyo), Sri Rejeki (Dukuh Brongkol), Ngudi Makmur I (SembuhLor), Rukun (Dukuh Sembuh Kidul), Ngudi Makmur II (Ganjahan V and VI), and Manunggal Karso (Ganjahan VII and VIII repairs) with the total members is about 604 farmers. In 2009 this Gapoktan received PUAP assistance as initial capital and was engaged in a savings and loan business unit. Three years later, in 2012, the Agribusiness Microfinance Institution (LKM-A) was formed to help farmers as Gapoktan members in capital or input farming. Furthermore, the formation of Gapoktan from the beginning has involved managers who have a rice business so that farmers who are members of Gapoktan can sell rice directly to Gapoktan. This is the key to the successful development of Gapoktan Sidomulyo, because this Gapoktan has owned capital as the driving factor (PUAP capital) and the market as the puller. The initial capital is the leverage factor of the success of Gapotan Sidomulyo, which is supported by managers who have managerial skills and the ability to build partnerships to expand markets and capital. [26] declares that a partnership will ensure a market for farmers' harvest with higher prices.

Gapoktan Sidomulyo, as an advanced farmer group, currently has six business units (Figure 1). This Gapoktan has fulfilled farmers' needs and has been able to bridge all farmers' interests to increase farmer's income with a better bargaining position from outside markets. Some important points that are driving and binding factors in Gapoktan are (1) Gapoktan management can open networks or partnerships with several entrepreneurs to market the products from farmers at a price based on an agreement that benefits farmers (2) The price of farming products, namely rice is sold at an average price averagely above the market price or through intermediaries who generally occur in every place and, (3) Provision of inputs by Gapoktan that can be used by farmers by taking and paying for without interest. 


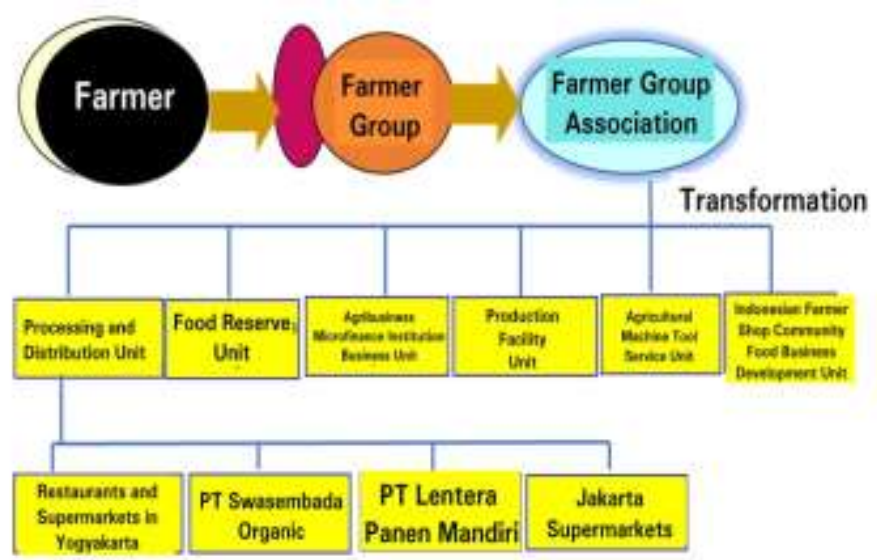

Fig. 1. Institutional transformation of Gapoktan Sidomulyo Data: The Year 2019

The processing and distribution business unit's main activities include: 1) Management and distribution of LDPM (Community Food Distribution Institution) producing environmentally friendly rice types IR 64, ciherang, mentik wangi, mentik milk, brown rice for restaurants and supermarkets in Yogyakarta; 2) Cooperation with PT. Jakarta's organic self-sufficiency (with MoU) for marketing organic Sidomulyo mix rice to meet KFC's needs (Kentucky Fried Chicken) in the Java region starting from September 2010 with an average shipment of 50-70 tons/month. 3) Cooperation with PT. Lentera Panen Mandiri to meet the needs of environmentally friendly brown rice grain and white rice for PT. Nestle Indonesia with an average shipment of 200 tons/month; 4) Distribution and marketing of organic milk mentik rice, organic fragrant mentik, black rice to Jakarta, and several supermarkets in Yogyakarta at 10 tons/month.

Farmers' satisfaction with Gapoktan services builds the commitment of farmers to implement and comply with the rules that are drawn up based on mutual agreement regarding; (1) agreement on the use of varieties in rotation by farmer groups and, (2) the use of organic fertilizers and other agreed regulations run according to the agreement. Besides, group coaching is carried out regulary once a month accompanied by a member meeting to evaluate the performance of Gapoktan members' work programs, which include:

1. Increase human resources in the management and management of Gapoktan business units

2. Improve administrative and financial management

3. Application of agribusiness microfinance institution business management

4. Capital accumulation from members

5. Increasing food reserves with the implementation of the Sidomulyo village food security perdes

6. Increased turnover of food distribution businesses

7. Increasing services for members' needs (inputs, services, Etc.)

Besides the excellent performance of management since it was based on a sense of belonging and a work ethic to develop Gapoktan, transparency of profits and profit-sharing become social capital in the management of Gapoktan. The success of financial management is based on several things, i.e. (1) Routinely annual reports to members, government, and related agencies, (2) Regularly meetings of members of Gapoktan, (3) Managers have various professions like farmers, traders, and administrator, (4) Synergy of all Gapoktan members who were able to work hard and (5) Provide benefits for members (income). 
The market as the pull factor of the Gapoktan business runs smoothly and continuously with a direct selling marketing system and delivery orders. Gapoktan's cash flow also continues to run smoothly with the marketing system. The partnership is running well because of the trust built by honesty and commitment between management and partners. The continuity of production supply is fulfilled by most of the Gapoktan members, and the shortage of demand is met by farmers from 19 other Gapoktan in the Sleman area while maintaining quality and quantity.

Performance of Gapoktan Sidomulyo as explained previously showed that Gapoktan Sidomulyo could be a model of farmer group association which mostly meets the requirements as an institutional organization of farmer corporation since it fulfill corporate management in accordance with Agricultural Minister Decree No. 18/ 2018, article 22, paragraph 1 as following : (1) The Farmer Corporation Institution is formed through integration carried out by the Farmer Group, and the Farmer Group Association in the form of a legal entity Farmers Economic Institution, (2) The legal entity Farmers Economic Institution in the form of a cooperative or other legal entity farmers with most of the capital ownership owned by farmers, and (3) The Farmer's Corporation is an integral part of this Agricultural Minister Decree whereas Farmer Corporation could receive facilitation for capital assistance, production infrastructure and facilities as well as technical and managerial assistance from government, private sector or non-governmental organizations

[27] Agricultural Minister Decree 18/2018, article 24 paragraph 1, explains in more detail that the farmer corporation institution can develop an independent business unit or include capital in an industrial or trading business group. (2) As referred to in paragraph (1), the development of an independent business includes the management of agricultural tools and machinery and capital participation in the form of agricultural tools and machinery that are not managed independently. Agricultural tools and machinery are the assets of farmers/farmer groups/farmer group associations, calculated as shares or equity participation in the Farmer Corporation institutional. Equity participation in corporate institutions must be confirmed with a cooperation agreement.

The requirements of farmer corporations, as stated in Article 22 paragraph 1, are empirically an impossibility because food crop farmers are small farmers who are characterized as farmers with a planting area less than $0.5 \mathrm{Ha}$ and unable to accumulate profits from the farming process and hence capital participation to develop business in groups is relatively difficult to be conducted. Even, refer to [26] statement that the distribution of farmers with a land area of less than 0.5 ha reaches 69 percent of the total food crop farmers in Indonesia.

Lesson learn from Gapoktan Sidomulyo provide a clear picture that the Gapoktan are the personal assets of one of the administrators that managed by Gapoktan. Meanwhile, the driving capital is the partners' investment capital and the loan capital of KUR funds as well as bank loans. Farmers' capital is only obtained through mandatory savings of Rp. 20.000 per month and principal savings of Rp. 5.000 per month, which amount is small from the investment capital. Mandatory savings and principal savings are primarily used as binders in groups.

Discussion with the Gapoktan's management also revealed a reluctance to develop Gapoktan into a legal farmer economic institution. Some of the reasons they mentioned are (1) the management of Gapoktan is well established currently, (2) the partnership has been going well and problems faced can be resolved as well, and (3) process to obtain legality through cooperatives or Limited Persero (PT) is considered quite difficult. Thus, some solutions that should be conducted are government intervention in helping the processing of legal entity and capital assistance for the management transformation of Gapoktan to be a farmer corporation as expected by the government. The socialization of the advantages of cooperatives and other legal entities also needs to be disseminated actively to the 
management and members of Gapoktan to form the advanced perception in the development of Gapoktan towards farmer corporations.

\section{Conclusion}

Farmer groups formed based on strong goals and supported by skilled human resources who have good managerial abilities in building partnerships and expanding the market and have assets from members as initial capital tend to develop quickly and successfully.

Farmer groups formed with the same goals but do not have the capital, skills, and business assets require maximum empowerment in various appropriate ways, such as assistance in managing their organizations and assistance in collecting business assets and business capital.

The approach that must be taken for transforming the advanced farmer groups into the farmer corporation is a social approach through government intervention in legal business processing and providing directions to develop the business. Improvement of human resource skills also needs to be a concern and even become an important target in government programs to empower the farmers.

\section{References}

1. R. Mutmainah, Sumardjo, J. Sos. Ped 2, 3 (2014).

2. S. Edi, Developing community strengthening people (2009)

3. Hermanto, Swastika, J. Agr. Poly 9, 4 (2011)

4. N.N. Mudege, T. Nyekanyeka, E. Kapalasa, T. Chevo, P. Demo, J. Rur. Stud 42 (2015)

5. E. Sraboni, H.J. Malapit, A. Quisumbing, A. Ahmed, W. Dev 61 (2014)

6. N. Desiana, A. Aprianingsih, A. J. Tech. Mang 10, 1 (2017)

7. A. Dolinska, P. D’Aquino, Agr. Syst 142 (2016)

8. H. Nassaji, J. Lang. Teach. Res 19, 2 (2015)

9. A. Yarcheski, Noreen, E. Mahon, Thomas, J. Yarchesky, Int. J. Nur. Stud 49, 9 (2010)

10. H. Atmowardoyo, J. Lang. Teach. Res 9, 1 (2018)

11. K. Dharamkar, A. Sailaja, R. Vasantha, Ecol. Env. Con 22, 2 (2016)

12. E. Tolno, H. Kobayashi, M. Ichizen, M. Esham, B.S. Balde, J. Agri. Sci 7, 3 (2015)

13. The law of Agriculture Ministry of Indonesia No. 67/Permentan/SM.050/12 (2016)

14. N. Saraswati, J. Avatra 4, 3 (2016)

15. N. Yenikawati, D. Denmar, A. Farida, J. Sos. Ekon. Bis 18, 2 (2015)

16. P. Egam, M.M. Rengkung, Med. Matr. Sain 11, 3 (2014)

17. F. Van. Rijn, B. Erwin, A. Adewale, Agr. Sys 108 (2012)

18. Christina, Maren, J. Int. Mar 4, 5 (2010)

19. A.Bakhtiar, R. Pulung, S. Indriani, I. Wahid, M. Shodiq, J. Soca 14, 3 (2020)

20. S. Ramadoan, P. Muljono, I. Pulungan, J. Soc. Econ. For. Res 10, 3 (2010)

21. Sukino, Developing agriculture through community empowering for reducing poverty (2013)

22. D.P. Kurniawati, B. Supriyono, I. Hanafi, J. Adm. Pub 1, 3 (2013)

23. W. Nasrul, J. Sci. T 3, 29 (2012) 
24. S. Nuryanti, S.K.D Swastika, Agro. Eco 29, 2 (2011)

25. Susanti, Affecting partnership for increasing vegetable farming system (Thesis, 2013)

26. Supomo, E. Nurhayati, Human resources management (2018)

27. The law of Agriculture Ministry of Indonesia No. 18/Permentan/RC.040/4 (2018) 